\title{
1. From record selling to cultural entrepreneurship: the music economy in the digital paradigm shift $^{1}$
}

\section{Peter Tschmuck}

\section{INTRODUCTION}

The digital revolution in the music industry ${ }^{2}$ has not just changed the concept of music distribution but also fundamentally reshaped its valueadded network. Companies that had no prior or at best only weak links to the music industry suddenly became a highly relevant part of it. Just think, for example, of Apple's dominance in the music download market. We can also find online retailers such as Amazon, the Internet search engine and micro advertising platform, Google, social media network, Facebook, and short messaging service, Twitter, more or less engaged in providing access to music. Whereas in the decades before the millennium music was relevant just for electronic media, the film industry, the games industry and the advertising industry, now companies from many other industries use music to sell their products and services: car manufacturers sell their latest models with car radios pre-programmed with popular music streaming services; airlines operate music download shops to offer bonuses in their customer relationship programmes if the customers buy music on their portals; supermarkets offer collector cards to download the latest hits from music online shops; and coffee house chains operate their own record labels to increase revenue by selling music.

Thus, music opens up new potentials of added value that go beyond the classical ways of selling music. However, copyright remains the crucial factor in the process of monetizing music. In continental Europe, the creators (authors and composers) are the ones who are exclusively entitled to exploit their rights. However, before the digital revolution, creators as well as performers depended on music publishers and record labels to disseminate their works. They therefore had to grant licences to 
the publishers and record labels of their music industry. Due to their dominant market position, the publishers and labels - almost always part of the same record company - insisted on receiving unrestricted and exclusive licences from the artists.

As a result of the digital revolution, however, artists have become less dependent on traditional players of the music industry. Numerous bands and single musicians began distributing their music directly through the Internet. A very early - and perhaps the most prominent - example is the British rock band, Radiohead. On 1 October 2007 Radiohead announced that their then latest album 'In Rainbows' was completed and would be released for free in ten days. Fans were instructed to obtain a registration code in order to download the new album in MP3 format. Music consumers were left to determine the price they were willing to pay for the download on their own - with the band setting the price range from US\$0.00 to US\$99.99. Fans' response was overwhelming, and within a few weeks more than 1.2 million downloads were counted. According to the Internet market research firm, comScore, 38 per cent of the fans paid an average of US\$6 per album, which resulted in US\$2.4 million in revenue. However, the unconventional album release turned out to be a clever promotion campaign for the deluxe $\mathrm{CD}$ version that became available for US\$81 two months later. In a very short time more than 100000 copies of the CD box were sold, resulting in additional revenue of US\$8 million (Kot 2009, pp. 232-40).

Radiohead demonstrated in spectacular fashion the potential of do-ityourself (DIY) marketing on the Net. The experiment, of course, worked so well because of Radiohead's popularity, but the dissemination of music to fans for free was successfully imitated by several lesser-known artists. They realized that even though their income from the direct sale of their music (for example, physical records, CDs, digital downloads) in the digital age was bound to be meagre, they would be able to boost their overall income by increasing revenue from concert tickets and merchandise if they promoted their music by distributing it for free.

The DIY approach, however, is not restricted to the direct distribution of music to fans. Crowdfunding campaigns are a new tool to pre-finance a record production, concert tour and marketing events. User-generated platforms (for example, YouTube), social media networks (for example, Facebook) and messaging services (for example, Twitter) assist artists in building a fan base and getting in touch with them. Artists nowadays can also directly collaborate with companies from other entertainment industries (games, movie, TV and so on) and open up new income sources by cooperating with the advertising industry. In fact, any company that 
needs music as content - whether telecommunications companies, transportation firms, hotels or restaurants - can become a business partner for artists. The latter's DIY approach, then, offers them new ways to generate income. In the following, I shall highlight several new possibilities of cultural entrepreneurship that go far beyond a simple DIY philosophy, while also attending to their challenges and limitations.

\section{THE VALUE-ADDED NETWORK IN THE DIGITIZED MUSIC INDUSTRY}

The record was the main revenue source in the traditional value-added network of the music industry. Music production and distribution were subordinated to the logic of selling records. Public relations (PR) and marketing aimed at maximizing $\mathrm{CD}$ sales, and even concerts were regarded as promotional tools for record sales. With the aid of the record, music publishers and record labels moved centre stage of the music industry in the 1950s at the latest (Figure 1.1).

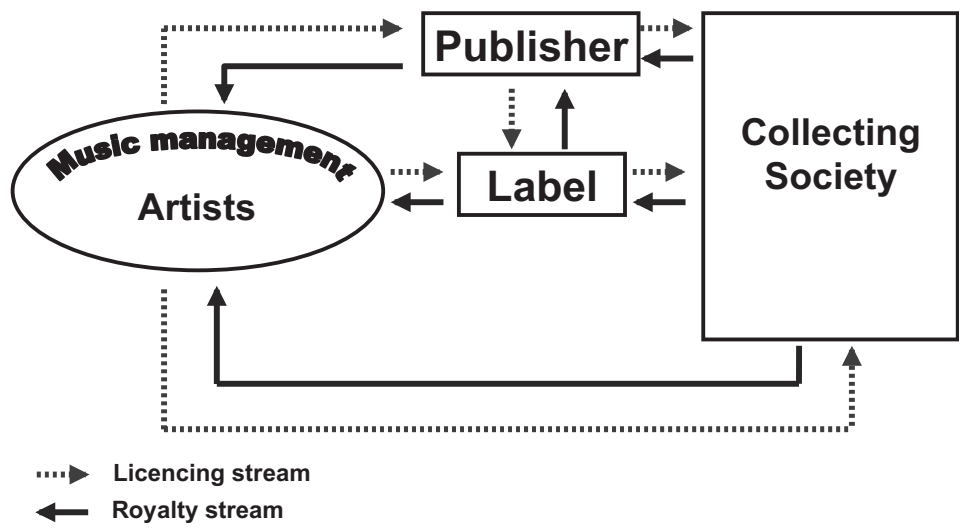

Figure 1.1 The streams of rights and royalties in the traditional value-added network of the music industry

The labels and the related music publishers were the main gatekeepers in the old record paradigm. Creators had to contract with a publisher to disseminate their works. For a singer/songwriter the record deal was the greatest business opportunity. The larger the record label, the more desirable was a deal for the artist and her or his management. The artist's revenue share from record sales, as contractually stipulated, served as a relevant income source: it enabled the artist to make a living provided a 
considerable number of records were sold. ${ }^{3}$ The creators as well as the performers could earn an additional income from the collecting societies that licence music for different uses. The musicians, therefore, had to contract exclusively to the publishers and the record labels to get their share from the records sold. This was not, however, a problem, since the artists could not produce the music by themselves and were not able to channel the records to the retailers. The cost of renting a professional recording studio was prohibitively high. The distribution networks were owned and operated by large music conglomerates, and the collection of royalties from different uses was nearly impossible.

Today, however, all these restrictions have been lifted. The computer has become the main hub of music production, and it is affordable now to operate a home recording studio. Content aggregators such as The Orchard, Believe Digital, Finetunes and Rebeat enable musicians to upload their work to distribute them to all music streaming and download portals worldwide such as iTunes, Amazon, Google and Spotify. ${ }^{4}$ Last but not least, creative commons licencing allows artists to control the usage of music apart from traditional collecting societies. Artists now have a network of supporting services at their disposal, which not only grants them autonomy from traditional players in the music industry but has also moved them into the centre of the industry's value-added network (Figure 1.2). In the following, I shall highlight the fundamental changes in all sectors of the value-added network that turned musicians from dependent contractors into artistic entrepreneurs.

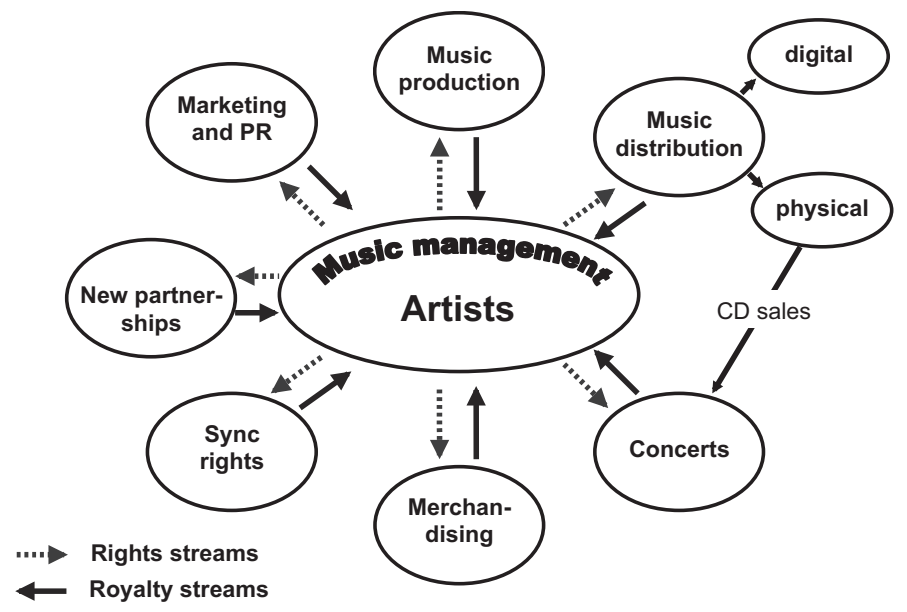

Figure 1.2 The streams of rights and royalties in the new value-added network of the music industry 


\section{Music Production}

The pre-financing of record productions is still a domain of the record labels. Nevertheless, new ways of financing such as crowdfunding allow artists to act independently from labels and other intermediaries. It was a headliner in the international press when the former Dresden Doll member, Amanda Palmer, collected more than US\$1 million on the Kickstarter crowdfunding platform for her latest album. More than 20000 fans backed the project financially with an average contribution of US $\$ 50$ per supporter. It was reported in the press that 35 supporters paid more than US\$5000 to facilitate the album release. ${ }^{5}$ The Palmer case makes the fundamental principle of crowdfunding visible (see, for example, Schwienbacher and Larralde 2010; Bartelt and Theil 2011). Crowdfunding platforms such as Sellaband, Kickstarter, IndieGogo, Startnext or mySherpas offer webpages for artists to present and promote their music projects (an album release, concert tour, marketing campaign for a new album and so on) to collect money from their fans in return for free CD copies, concert tickets and other rewards. The total amount needed and the price scheme have to be defined in advance by the artists. On some platforms, the project can only be realized if the defined amount can be collected (all-or-nothing platforms), whereas on others the artists get the money even when the crowdfunding campaign did not reach its goal (in this case the artists still have to deliver the promised rewards to their supporters).

Although crowdfunding has its historical predecessors, ${ }^{6}$ the Internet enables artists to approach a worldwide audience of potential supporters. Nevertheless, this new instrument of financing is just in its infancy. A study of the Institute for Communication in Social Media (ikosom) for the German speaking countries highlights that most of the crowdfunding platforms have only been in existence for a very short time. Apart from Artistshare, which was established in 2003, most of the platforms were founded after $2005 .^{7}$

The ikosom (2012) study highlighted ten album releases that were offered for support between June 2010 and April 2011 on six crowdfunding platform operating in Germany. Three out of ten were successfully financed. An average of 85 supporters per album contributed 2699 euros - an average of 35 euros per supporter. ${ }^{8}$ Furthermore, an Austrian study (Palmsteiner and Wörginger 2013) of eight newcomer bands shows that the median support of the projects lies within a span of 15 to 50 euros, whereas the average financial support of a backer was higher, varying from 40 to 100 euros. This indicates that most backers only contribute smaller amounts, while only a few donate higher sums of 
money, which, however, are instrumental in ultimately enabling most such projects. However, just half of the projects - with target amounts from 800 to 10000 euros - were successfully financed. Crowdfunding, therefore, is not a fully fledged alternative to the funding of traditional album releases by record labels; it is, however, an instrument that artists can use to communicate with fans and involve them in their projects. Therefore, crowdfunding helps to assess the scope of the fan base, which can be monetized by the artists with the help of booking agents, concert promoters, record labels and other business partners.

\section{Music Distribution}

According to the latest International Federation of the Phonographic Industry (IFPI) report (IFPI 2015, p. 7), the global digital music sales outperformed physical sales for the first time in 2014. In ten out of the top 20 largest recorded music markets, digital sales accounted for more than half of the total revenue. Scandinavian countries (Sweden 73 per cent and Norway 72 per cent) and China (87 per cent) are leaders in the digitized music market, but the United States closely follows with a digital market share of 71 per cent (IFPI 2015, p. 7). The figures confirm that the recorded music industry is in the middle of the digital paradigm shift with digital music outperforming record sales.

Thus, digital music distribution grows increasingly important and helps artists to emancipate themselves from record labels. They can use content aggregators such as The Orchard, Believe Digital, Finetunes and Rebeat to channel their music to a vast number of music streaming and download portals worldwide such as iTunes, Amazon, Google and Spotify. The Austrian digital music distribution platform Rebeat (http:// www.rebeat.com) allows the uploading of music tracks with a software package that has to be installed on the computer. Tracking software shows on which portals the tracks are available. Widgets can be integrated in Facebook, MySpace and in the artist's webpage to play music samples. The software also provides the clearance of the tracks sold and shows the sales on the different platforms as well as the expected payments. A rights management system calculates copyright fees payable to collecting societies and to other business partners, if necessary. The artist is able to control, therefore, the whole process of digital music distribution including clearance and rights management.

Whereas digital music sales have become ever more relevant, CD sales continue to dwindle. Despite a high market share of the physical product in Japan (78 percent) and in Germany (70 per cent) in 2014 (IFPI 2015, p. 7), it is expected that CDs will have the same fate as vinyl records, 
which today mostly serve a small, albeit growing, market of analogue enthusiasts. CDs are still an important object of prestige, but they essentially function as business cards to be handed to concert promoters, music journalists, fans and so on.

In 2015, a blog post offered a calculation of how many units of different music formats (CDs, album downloads, music streams and so on) are needed to equal the monthly minimum wage in the United States of US\$1260. An artist/band would have to sell 105 units of a selfproduced and distributed $\mathrm{CD}$ to earn the minimum wage. If the $\mathrm{CD}$ were distributed by retailers at US\$12, the number of units would have to rise to $818 ; 11364$ digital units would have to be sold via Amazon and iTunes store to get the same amount. Last but not least, the album would have to be streamed 4.5 million times on YouTube to earn the same amount (Figure 1.3).

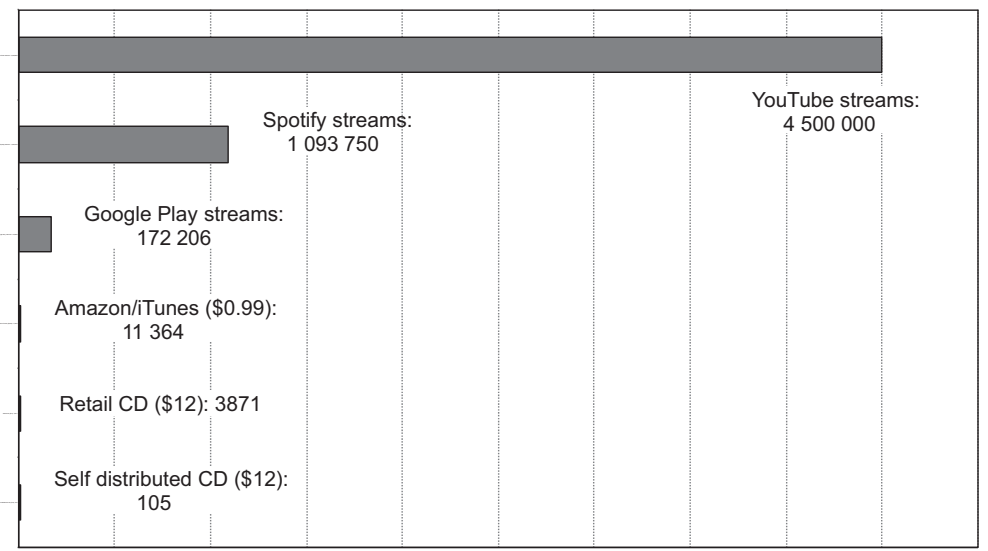

Source: http://www.informationisbeautiful.net/2010/how-much-do-music-artists-earnonline/.

\section{Figure 1.3 How many units have to be sold of different music formats to earn the minimal wage of US\$1260?}

As the figures suggest, it is still impossible for most artists to earn a living by selling music. If music streaming becomes more relevant, the economic situation for musicians will become even worse. However, streaming can be a useful tool to gain attention and to promote concerts. 


\section{The Concert Business}

If one examines the earning lists for superstars of the music business, one notices that touring and festivals are the main revenue source for them. Thus, Taylor Swift, who headed the Billboard top 40 money makers list in 2013, ${ }^{9}$ earned US\$30 million from the 'Red' Tour in the United States alone, which was a 75 per cent share of her total earnings in 2013. The remaining US\$9.7 million came from record sales, download sales (10 million units), streaming, publishing royalties and merchandising. Beyoncé, who ranked sixth in the Billboard list, earned US\$19.9 million from her 'Mrs. Carter Show World Tour', which made up 81.5 per cent of her total income in 2013. It is striking that all of the top ten artists earned more than 60 per cent of their total income from touring.

The international concert market has boomed in the past few years. The boom is fuelled, on the one hand, by the digital paradigm shift that forces even superstars to tour regularly and, on the other hand, also by the structural interruption in the live music industry. Until the 1990s the concert market was organized on a regional and even local level. However, the market entrance of SFX Entertainment at the end of the 1990s revolutionized the concert and touring business. SFX grew by acquiring a vast number of concert promoters in the United States, among which the most important ones included Bill Graham Presents, PACE Entertainment, Concert/Southern Promotions and Contemporary Productions. After the broadcasting conglomerate Clear Channel bought SFX Entertainment for US $\$ 4.4$ billion in 2000 , the music promoting business was spun-off as Live Nation Inc. in 2005. At that time Live Nation was already the world's largest concert promoter. In 2009, Live Nation merged with the world's largest ticketing company, Ticketmaster, in a US\$2.2 billion all-stock deal. Since Ticketmaster had bought Front Line Management, one the most relevant artist management firms, the new conglomerate controlled not just the global concert promotion and ticketing market but also the artist management business. ${ }^{10}$

Live Nation and a few other players such as the Anschutz Entertainment Group (AEG) and CTS Eventim AG have turned the former localized concert business into a billion dollar industry. Since these giants can afford to pay artists a share of 80 per cent and more in revenue from ticket sales, touring has become a lucrative business for the superstars. It is, thus, no surprise that veterans such as The Rolling Stones, Fleetwood Mac and Bon Jovi toured the world in 2013.

However, the high density of superstars on tour is a challenge for emerging and newcomer acts. The competition for a live audience is fierce as never before. In addition, the live music market growth is also 
limited. The German concert market, for example, shrunk by 19.5 per cent from 2007 to 2009, but grew to 2.7 billion euros in 2013, which is still below the all-time high of 2007 (GfK 2014, p. 2). At the same time, the shows have become more elaborate, driving the costs to all-time highs. In addition, the stars demand an even higher share of ticket sales, which lowers profit margins. ${ }^{11}$ Nevertheless, revenue from concerts and touring has become the most important income source for performing musicians, whether they are superstars or not.

\section{Merchandising and Branding}

Merchandising is closely linked to the live music business. Merchandising covers the production, distribution and promotion of fan articles that have the same logo and deliver the same message as a branded article. The artists are the brands in the music business. Thus, the artist's branded image can be monetized by T-shirts, caps, scarves and other apparel. These commodities can be sold at a higher than market price, which is a welcome additional income source for musicians. It is reported ${ }^{12}$ that Bon Jovi earned US\$2 million from merchandising articles, which is significantly higher than their revenue from downloading sales of US\$300 000 .

It has become common for superstars to monetize their brands. Beyoncé Knowles established the fashion line 'House of Deréon' in $2005^{13}$ to sell sportswear, handbags, shoes and other apparel in retail chains in North America. HipHop and Rap acts have a particular preference for fashion lines (see Charnas 2010). In 'Diamonds from Sierra Leone' Jay-Z raps, 'I sold kilos of coke, I'm guessin' I can sell CDs. I'm not a businessman, I'm a business, man!'

\section{Rights Management and Music Licencing}

The control of all rights related to music production and music distribution is essential for artists in the digital age. Especially synchronization rights that allow music to e-connect with other media content have become increasingly important as a revenue source. In 2014, US $\$ 189.7$ million of revenue from sync rights were collected from the rights holders (IFPI 2015, p. 65). Previously, it was common to assign sync rights to the music publishers in order to licence them to movie and TV producers, games developers as well as advertising agencies. It is rumoured that licencing a superstar hit costs up to a five-digit euro amount. ${ }^{14}$ Thus, entertainment companies seek to collaborate with 
lesser-known and especially newcomer acts to commission them to compose works used in games, commercials, movies, TV productions and so on.

Big games developers even employ their own composers who deliver music for the latest games. However, most of the music in games is commissioned from independent composers who focus on composing for games. A few years ago, music games were very popular. A game console allows gamers to perform with their favourite band or dance and sing along with someone like Michael Jackson. However, these games are not just for superstars; they also serve as a platform for lesser-known acts. Music games such as 'Guitar Hero 3' with 15.5 million units sold or 'Rock Band: The Beatles' with 3.5 million units sold are by any measure a remarkable source of income for superstars. ${ }^{15}$

The advertising industry also becomes increasingly important for the artists. The collaboration of the phonographic industry and the advertising industry goes back to the late nineteenth century, when Tin Pan Alley music publishers supplemented sheet music to newspapers and magazines that were sponsored by advertisers. The collaboration continued in the 1920s when commercial radio surfaced and entire music shows were sponsored by tobacco firms, soft drink producers and car manufacturers. When the advertising money was shifted from radio to TV by the large networks in the 1950s and 1960s, the close relationship between advertisers and record labels loosened (see Wang 2012).

In the course of the digital revolution, the advertising industry became once again relevant for the music industry. In 2010, rap superstar Nicki Minaj entered into a perennial cooperation with Pepsi. The deal includes, for example, the integration of the hit 'Moment for Life' in an advertising campaign. ${ }^{16}$ The Trinidad \& Tobago singer thus follows in the footsteps of Michael Jackson, who revolutionized music sponsoring with his Pepsi deal in 1983. However, newcomers and lesser-known acts also have the chance to find an audience through cooperating with advertisers. For example, Nashville-based singer/songwriter Jessica Frech attracted the attention of South Korean car manufacturer Hyundai with her music videos on YouTube. Hyundai commissioned a song for a US-wide advertising campaign with Frech as a performer. ${ }^{17}$ This TV appearance made the singer/songwriter popular with more than 77000 subscribers of her YouTube channel. ${ }^{18}$

Therefore, it could be lucrative for artists to collaborate with games developers, film studios, TV production firms, advertising agencies as well as advertisers to gain new revenue streams and to raise their popularity. 


\section{New Business Partners}

The production of a record is no longer a monopoly of record labels. Companies from outside the music industry have taken over this core competence. In March 2007, coffee house chain Starbucks established its own record label - Hear - to release Paul McCartney's first record after leaving EMI. ${ }^{19}$ James Taylor, Joni Mitchell and Carly Simon followed suit and also released records on the Starbucks label (Knopper 2009, p. 245). Since, however, the expected increase of revenue in the core business did not happen, Starbucks sold its share in Hear Music to the Concord Music Group in April 2008. ${ }^{20}$

Wal-Mart is another example of how a music business outsider became engaged in the recorded music industry. In fall 2007, the US retail chain giant started to exclusively distribute The Eagles' studio album, 'Long Road Out of Eden', which was produced with the support of Wal-Mart (Knopper 2009, p. 245). Wal-Mart was also a pioneer in digital music distribution. Shortly after Apple launched its iTunes store, the company set up a music download platform on the Internet. However, Wal-Mart's download shop was marginalized by iTunes and was shut down in August 2011.21

Wal-Mart is a good example of a music business outsider that failed to establish itself in the music industry, since it was not able to provide an additional benefit apart from selling music. It is a well-known fact that Apple's iTunes store did not break even until nine years after its launch and still operates in several countries at a loss, especially in the music download segment. ${ }^{22}$ Nevertheless, the music downloads are important for Apple to sell its various devices - Macs, iPods, iPads and iPhones. For online trader Amazon.com, music is a loss leader to generate traffic on its homepage to motive consumers to buy products with high profit margins. Therefore, a partnership with music industry outsiders only makes sense if artists can provide added value. Many companies from other branches such as telecommunications, transportation (for example, airlines, bus operators), gastronomy, hotel industry and so on need music content to valorize their core products and services. Thus, the production of an additional benefit for those new business partners is a promising source of revenue.

\section{PR and Marketing}

Music PR and marketing were also exclusive domains of the record labels. Today, social media and user-generated content platforms on the Net can attract a mass audience that previously could only be reached by 
traditional media. Thanks to Justin Bieber's mother, who uploaded videos of Bieber playing guitar on YouTube, his talent was recognized by music manager Scooter Brown and HipHop musician and producer Usher Raymond. They signed the 13-year-old boy for their agency to contract him with Universal Music Group's sub-label Island Records. ${ }^{23}$ In Bieber's case, the Internet was just the springboard to a very traditional career in the music business.

For the British-Portuguese singer/songwriter Ana Free, YouTube and social media are essential in her business model. In January 2007, Ana Free posted videos of her performances sitting on the couch of her living room for the first time. At the end of the same year, her videos had been clicked 700000 times. This attracted the attention of the Portuguese telecommunications company Zon, which used the song 'In My Place' in a TV spot in 2008. Ana Free's appearance on TV turned her into a star in Portugal. The number of downloads exploded, and 'In My Place' topped the iTunes charts in Portugal for three months. The economic success enabled the artist to produce the EP 'Radian', which was released in 2010. As a result, Ana Free was booked for gigs in Miami and New York City, and superstars such as Shakira and James Morrison invited her for guest appearances in their shows. From this moment on, music clubs and concert promoters from around the world tried to book her for their programmes. All these activities further increased Ana Free's popularity. Her video channel on YouTube counts more than 86000 registered followers, and her music videos have been viewed 35 million times up to the time of writing. In 2013, she was the music face of the new Beetle Cabriolet ASAP Campaign, and she released her debut album 'To Get Her' after successfully collecting more than $£ 10000$ on crowdfunding platform Pledge Music. ${ }^{24}$ Ana Free launched her career without management, booking agency or record label. The main communication hub is not her homepage but Facebook, YouTube, Twitter and Instagram.

Ana Free and several other DIY artists evidence that musicians can launch sustainable careers apart from traditional players in the music industry. Therefore, it is important to link new and old media in a communications mix. In the digital age, it is no longer sufficient to launch a career solely through TV and radio. However, new media alone cannot break an artist either. All cases highlight the continued importance 'old' media have for artists at a certain stage in their careers. Social media and user-generated content platforms provide important input for traditional media formats, but they, in turn, provide necessary feedback on the new media channels. 


\section{THE NEED FOR ARTEPRENEURSHIP}

\section{From Record Selling to 360 Degree Deals}

The digital revolution has moved the artist centre stage in the music industry. The key players in the music industry anticipated this development by establishing the concept of so-called 360 degree deals. In this respect, EMI was a forerunner by offering Robbie Williams a 'unified rights deal' in 2002. In return for advance payments of US\$160 million, EMI did not only get the usual share in Williams's record sales but also benefited from his publishing royalties and his concert revenues. 360 degree contracts became a standard after Live Nation signed Madonna in a US $\$ 120$ million deal in October 2007. The deal includes not only digital and physical sales but also concerts and tours promoted by Live Nation as well as merchandising, sponsoring, branding and fan club relations. Thus, Live Nation can cross-collateralize all income sources, which lowers the financial risk. Live Nation subsequently entered into an additional 360 degree deal with Irish pop band U2 (US\$100 million for 12 years) in March 2008 that includes touring, merchandising and licencing of image rights, website design and fan club relations. In April 2008, Jay-Z signed a ten-year US\$150 million deal with Live Nation that encompasses touring, recording, publishing and artist management. Shakira's US\$70 million Live Nation deal of July 2008 covers touring, merchandising and recording. Also in 2008, the Canadian rock band Nickelback received a three-album deal for US\$50-70 million covering recording and touring (Budnick and Baron 2011, pp. 309-10).

It is striking, however, that Live Nation entered into just a few 360 degree deals after 2008. This might be a sign that the existing deals were not as profitable as expected. Since Live Nation is focused on the promotion and ticketing business, it has to gain additional expertise in recording, publishing, merchandising, artist management, fan club relations and so on. A 360 degree deal makes sense for an artist if the partner is able to perform all the tasks on a professional level.

Warner Music Group (WMG) has offered its artists so-called 'expanded rights agreements' since 2004 to benefit not just from recording and publishing revenues but also from live performances and artist management. Warner, therefore, acquires and collaborates with several artist agencies to gain this new expertise. The business segment of 'artist services' and 'expanded rights agreements', however, represented just 11 per cent of the total revenue during the fiscal year 2014, which is modest compared to the recording revenue, which accounted for nearly two thirds of the total annual income (Warner Music Group 2015, p. 42). 
Nevertheless, all of the major recording companies as well as most of the indies offer their acts 360 degree deals. The Vienna-based ink Music company operates not just a record label (schoenwetter) but also a booking agency, a PR agency, a music publisher and a sync rights agency (swimming pool). Thus, the revenue from different sources can be cross-collateralized.

Nevertheless, the question arises whether artists still need a record label and other intermediaries to become financially successful. Most of them do not have any choice. They have to adopt the DIY approach. Even successful artists, however, get along without a strong business partner. When the very successful German rapper Cro was asked by a magazine if he needed a record label, he argued that he and his management could do anything by themselves. 'We invested all our money. We worked out poster designs and pre-financed concerts. Today one needs just a laptop and supportive people. Shit on the major labels.' ${ }^{25}$

Therefore, the artists have to gain expertise in the functioning of the music business and in self-management. There is a need for music business education at all levels from schools to universities. Since an artist needs time for his core competencies, music making and performing, it makes sense to get support from professional management, if this is affordable. Instead of the former long-time relationship with a record label, artists can now enter shorter-term collaborations with record companies as well as with other partners in the value-added network. Since the artist is centre stage in the new digitized music economy, she or he can benefit from very different income streams, as pointed out above. In this respect, music making is a 360 degree task in the early twenty-first century that covers economic and legal aspects in addition to the core artistic competencies. Engelmann et al. (2012) therefore coined the term 'artepreneur'. The artepreneur has to act at the interface of the artistic as well as economic spheres to launch a sustainable and successful career in the music business.

\section{Artepreneurship and Music Prosumption}

Artepreneurship, however, is a transitional phase to a much more far-reaching change. The digital revolution merged the spheres of active music making and passive music consumption. Users want to participate in the music production and distribution process. They comment on music blogs, set up profiles in social media networks, use Rich Site Summary (RSS) feeds, post music on their blogs, upload music videos on YouTube and remix existing music tracks. This increasing participation of music fans in music production and distribution indicates the change 
from push music culture, which was practised by media houses for decades, to a pull music culture, in which consumers decide what they want. More than merely a DIY culture, it is the emergence of a network of production, distribution, communication and consumption processes that take place simultaneously. This can be referred to as music prosumption, a term coined by Alvin Toffler in his bestseller The Third Wave in 1980. A prosumer is a person who consumes what she or he produces by her or himself. Media scientist Marshall McLuhan and Barrington Nevitt outlined the prosumption concept in Take Today in 1972 for the first time. They highlighted that electronic media has the potential to turn consumers into producers and vice versa.

Their prophecy became reality 40 years later. Today, music fans participate in the production, distribution and communication of music. As the crowdfunding example highlights, fans pre-finance music productions and concerts. However, this is just one aspect of a much broader concept of crowdsourcing. Howe (2008, pp. 281-2) defines crowdsourcing as 'the act of taking a job traditionally performed by a designated agent (usually an employee) and outsourcing it to an undefined, generally large group of people in the form of an open call'. Howe subsumes under crowdsourcing not just crowdfunding but also crowdwisdom, crowdcreation and crowdvoting.

Crowdwisdom means that the knowledge of a large group is superior to individual knowledge. This results in collective intelligence of social networks to foster innovation such as Wikipedia. Crowdcreation is based on utilizing the creativity of a large group of people to create new content. YouTube is the best example for such a user-generated content platform. In crowdvoting the judgement of large groups unveils collective preferences and trends as in the case of ratings on webpages. To sum up, the different instruments of crowdsourcing can be used by companies as well as artists to benefit from collective creativity on the Net. Crowdsourcing is, therefore, just one aspect of prosumption.

In the club and DJ culture prosumption is an integral part of the creative process. A DJ is part of a scene and benefits from the creative and financial inputs of her or his fans. Lange and Bürkner (2010, pp. 61-64) observe a hybridization of value-added processes. The material and socio-cultural dimensions of the value-added process are closely linked. Thus, music creation cannot be separated from its economic exploitation. The artist, who is strongly dependent on live performances, creates derivative works and acts as prosumer. The scene, however, creates or destroys the DJ's reputation and economic fortune. Thus, music fans are directly involved in the value-added processes, and the traditional (see Figure 1.1) division of labour between artists and fans 
becomes obsolete. Fans as well as artists create market value that can be monetized outside the music scene by branding, merchandising and selling sync rights. The record is just a calling card and a symbol of the artist's artistic development. In an endless stream of music creation the narrow concept of a musical work disappears. The result of the artistic process is no longer merely a song but a music track that can be manipulated and changed. The main aim is not the finished piece of music but the creation process of music itself. Thus, music is used and further developed in a prosumption process apart from passive music consumption.

\section{SUMMARY}

The value-added network in the music industry was revolutionized in the course of digitization. The record used to be the centrepiece of value creation, and the labels were the gatekeepers in the value-added processes. Digitization destroyed the traditional relations, and the artist moved centre stage in the value-added network of the music industry. Due to decreasing production costs artists are enabled to produce music literally in their living rooms, and they can pre-finance a record production with the help of crowdfunding campaigns. Artists can disseminate their music worldwide on the Internet with the support of content aggregators that channel music directly to consumers aside from the labels' distribution infrastructure. Live music performances have become the most important income source for artists as long as a broad fan base exists. Artists can generate additional income by branding and merchandising as well as by selling synchronization rights to TV and film producers, games developers and advertising agencies. Artists can also collaborate with partners from outside the traditional music business in temporary projects to tap new income streams. Social media sites and user-generated content platforms enable musicians to market and promote themselves to a global audience.

In contrast to the former record paradigm, today it is no longer sufficient to earn a living from just one income source. Musicians need different revenue streams to launch a successful career. Artistic talent, therefore, has to be merged with economic knowledge in the concept of artepreneurship. Active music creation and passive music consumption, however, are not separate spheres any longer. Music fans participate in the production, distribution and communication of music and use and change music for their own purposes. This results in a process of music 
prosumption in which music is used and changed in an endless collective creative process.

Therefore, the music sector is different to other entertainment sectors such as the TV and film industry. Whereas the digitized music industry is mainly driven by artists as content providers, TV and film production is still connected with comparably high investment and is much more dominated by the division of labour than music production. Thus, distribution is still the bottleneck in the film business (see Cunningham and Silver 2012). In the music industry digital music distributors (such as The Orchard, Finetunes and Rebeat) as well as digital music retailers (such as iTunes, Amazon, Google and Spotify) are more or less service providers for the rights holders (artists as well as record companies). The digital music retailers especially are highly dependent on licencing music for their services. Taylor Swift's decision to withdraw her song catalogue from music streaming service Spotify highlights the new power of a well-established superstar.

Whereas distribution is still king in the TV and film industry, content is the main currency in the music business. This might change if music distributors start to acquire the major record companies and their vast music catalogues to save transaction costs. If that happens, the valueadded network in the music industry will again be revolutionized and the artists' strong position will then be challenged.

\section{NOTES}

1. This chapter is a revised and extended version of 'Das $360^{\circ}$-Musikschaffen im Wertschöpfungsnetzwerk der Musikindustrie' that was published in 2013 in B. Lange, H.- J. Bürkner and E. Schüßler (eds), Akustisches Kapital. Wertschöpfung in der Musikwirtschaft, Bielefeld, transcript, pp. 285-316.

2. For a detailed explanation of why the music industry underwent revolutionary rather than merely gradual change see Tschmuck (2012).

3. Business insiders estimate that only 20 per cent of all releases were able to cover the production costs. Just a small number of those 20 per cent were the cash cows that had to cover the losses of the remaining 80 per cent. Musicians, therefore, were paid royalties when the production was break-even. Thus, just a small number of artists were privileged and well-earning stars of the music business.

4. Music content aggregators such as The Orchard are digital music wholesalers that distribute the music files to the digital music retailers such as iTunes. Digital music wholesalers as well as retailers can be subordinated to the category music distribution in Figure 1.2.

5. Billboard.biz, 'Amanda Palmer hits $\$ 1$ million mark on Kickstarter campaign', 28 May 2012 .

6. It was common practice for impresarios and composers to set up so-called subscription opera and concert projects to solicit pre-funding from aristocrats and wealthy bourgeois in the eighteenth century. The operas and concerts were staged if the defined amount of money could be collected in advance (see Dahlhaus 2008, pp. 189-90). 
7. The forerunner in the German speaking countries, Sellaband, was initially founded in the Netherlands, but it went bankrupt in 2010. The assets and the brand were bought by a German investment fund, and Sellaband was re-established in February 2010 (NRC Handelsblad, 'After bankruptcy, investors take on Sellaband's debts', 25 February 2010).

8. Apart from music albums, games, marketing campaigns, magazines, book publishing projects, art projects, start-ups, scientific studies, development aid projects, movies, radio dramas and events were also promoted on the platforms during the research period.

9. Billboard.biz, 'Music's top 40 money makers 2014: the rich list', 10 March 2014.

10. For the emergence and history of Live Nation see Budnick and Baron (2011).

11. Bundesverband der Veranstaltungswirtschaft, 'Bundesverband und Musikmarkt veröffentlichen aktuelle GfK-Studie zum Veranstaltungsmarkt', press release, 26 July 2012.

12. Billboard.biz, 'Music's top 40 money makers 2014: the rich list', 10 March 2014.

13. See http://www.houseofdereon.com/ (accessed 27 August 2012).

14. See an interview of the president of the Austrian Association for Entertainment Software, Niki Laber, in 'Die Relevanz des Spielemarkts für das Musikbusiness', 15 March 2011.

15. See http://www.gamrreview.com/ (accessed 5 June 2014).

16. Billboard.biz, 'Pepsi teams with Nicki Minaj', 1 May 2012.

17. Billboard.biz, 'Auto tune: who's the girl in that Hyundai TV commercial?', 21 December 2011.

18. http://www.youtube.com/jessica.frech.

19. Starbucks, 'Starbucks launches Hear Music record label', 12 March 2007.

20. Starbucks, 'Starbucks refines its entertainment strategy', 24 April 2008.

21. New York Times, 'After 7 years, Wal-Mart closes its MP3 store', 9 August 2011.

22. Billboard.biz, 'If iTunes is still breaking even, it could cost $\$ 1.3$ billion per year to run', 14 June 2011.

23. New York Times, 'Justin Bieber is living the dream', 31 December 2009.

24. Billboard.biz, 'How Ana Free became a YouTube phenom, topped charts, opened for Shakira without label or mgmt', 14 February 2012 and http://www.anafree.com.

25. Profil, 'Jeder Song muss Bombe sein', 6 June 2014.

\section{REFERENCES}

Bartelt, D. and A. Theil (2011). 'Crowdfunding - Der neue Weg für private, öffentliche und unternehmerische Förderung in der Kultur- und Kreativwirtschaft, Teil F 3.7', in F. Loock and O. Scheytt (eds), Kulturmanagement \& Kulturpolitik. Die Kunst Kultur zu ermöglichen. Stuttgart: Dr Josef Raabe Verlag, pp. 2-30.

Billboard.biz (2011). 'If iTunes is still breaking even, it could cost $\$ 1.3$ billion per year to run', 14 June, available at http://www.billboard.biz/bbbiz/industry/ digital-and-mobile/business-matters-if-itunes-is-still-breaking-1005230542. story (accessed 6 June 2014).

Billboard.biz (2011). 'Auto tune: who's the girl in that Hyundai TV commercial?', 21 December, available at http://www.billboard.biz/bbbiz/industry/ branding/auto-tune-who-s-the-girl-in-that-hyundai-1005718572.story (accessed 6 June 2014).

Billboard.biz (2012). 'How Ana Free became a YouTube phenom, topped harts, opened for Shakira without label or mgmt', 14 February, available at http:// www.billboard.biz/bbbiz/industry/indies/how-ana-free-became-a-youtube-phenomtopped-1006076382.story (accessed 6 June 2014). 
Billboard.biz (2012). 'Pepsi teams with Nicki Minaj', 1 May, available at http://www.billboard.com/news/pepsi-teams-with-nicki-minaj-preps-michael1006917152.story\#/news/pepsi-teams-with-nicki-minaj-preps-michael-10069 17152.story (accessed 5 June 2014).

Billboard.biz (2012). 'Amanda Palmer hits \$1 million mark on Kickstarter ampaign', 28 May, available at http://www.billboard.biz/bbbiz/industry/indies/ amanda-palmer-hits-1-million-mark-on-kickstarter-1007172152.story (accessed 3 June 2014).

Billboard.biz (2014). 'Music's top 40 money makers 2014: the rich list', 10 March, available at http://www.billboard.com/articles/list/5930326/music-stop-40-money-makers-2014-the-rich-list (accessed 4 June 2014).

Budnick, D. and J. Baron (2011). Ticket Masters: The Rise of the Concert Industry and How the Public Got Scalped. New York: ECW Press.

Bundesverband der Veranstaltungswirtschaft (BdV) (2012). 'Bundesverband und Musikmarkt veröffentlichen aktuelle GfK-Studie zum Veranstaltungsmarkt', Press release, 26 July, available at http://www.bdv-online.com/sites/default/ files/presse/PM\%20GfK-Studie_120725.pdf (accessed 4 June 2014).

Charnas, D. (2010). The Big Payback: The History of the Business of Hip-Hop. New York: New American Library.

Cunningham, S.D. and J. Silver (2012). Digital Disruption: Cinema Moves Online. St Andrews, Fife: St Andrews Film Studios, University of St Andrews.

Dahlhaus, C. (ed.) (2008). Geschichte der Musik. Volume 5: Die Musik des 18. Jahrhunderts. Laaber: Laaber-Verlag.

Engelmann, M., L. Grünewald and J. Heinrich (2012). 'The new artrepreneur how artists can thrive on a networked music business', International Journal of Music Business Research, 1(2), 32-46.

GfK (2014). Konsumstudie des Veranstaltungsmarktes 2013, ed. Bundesverband der Veranstaltungswirtschaft and Musikmarkt magazine.

Howe, J. (2008). Crowdsourcing: Why the Power of the Crowd is Driving the Future of Business. New York: Three Rivers Press.

IFPI (2015). Recording Industry in Numbers 2015 - The Recorded Music Market in 2014. London: IFPI.

ikosom (2012). Crowdfunding Studie 2010/2011. Untersuchung des plattformbasierten Crowdfundings im deutschsprachigen Raum, Juni 2010 bis Mai 2011. Berlin: Institut für Kommunikation in sozialen Medien.

Informationisbeautiful (2015). 'How much do music artists earn online?', 7 April, available at http://www.informationisbeautiful.net/2010/how-much-domusic-artists-earn-online/ (accessed 28 May 28 2015).

Interview of Niki Laber in 'Die Relevanz des Spielemarkts für das Musikbusiness' (2011). 15 March 15, available at http://musikwirtschaftsforschung. wordpress.com/2011/03/15/die-relevanz-des-spielemarkts-fur-das-musikbusiness/ (accessed 4 June 2014).

Knopper, S. (2009). Appetite for Self-destruction: The Spectacular Crash of the Record Industry in the Digital Age. New York: Free Press.

Kot, G. (2009). Ripped: How the Wired Generation Revolutionized Music. New York: Scribner. 
Lange, B. and H.-J. Bürkner (2010). 'Wertschöpfung in der Kreativwirtschaft. Der Fall der elektronischen Klubmusik', Zeitschrift für Wirtschaftsgeographie, 54(1), 46-68.

McLuhan, M. and N. Barrington (1972). Take Today: The Executive as Dropout. New York: Harcourt Brace Jovanovich.

New York Times (2010). 'Justin Bieber is living the dream', 3 January, available at http://www.nytimes.com/2010/01/03/fashion/03bieber.html?pagewanted=all (accessed 28 August 2012).

New York Times (2011). 'After 7 years, Wal-Mart closes its MP3 store', 9 August, available at http://mediadecoder.blogs.nytimes.com/2011/08/09/after7-years-wal-mart-closes-its-mp3-store/ (accessed 5 June 2014).

NRC Handelsblad (2010). 'After bankruptcy, investors take on Sellaband's debts', 25 February, available at http://vorige.nrc.nl/international/article 2491973.ece (accessed 3 June 2014).

Palmsteiner, F. and G. Wörginger (2013). Crowdfunding: Ein Finanzierungsinstrument für Newcomer-Bands? Vienna: Vienna University of Economics and Business Adminstration.

Profil (2014, print edition). 'Jeder Song muss Bombe sein', 6 June 2014.

Schwienbacher, A. and B. Larralde (2010). 'Crowdfunding of small entrepreneurial ventures', 28 September, available at http://dx.doi.org/10.2139/ ssrn.1699183 (accessed 22 August 2015).

Starbucks (2007). 'Starbucks launches Hear Music record label', Press release, 12, March, available at http://news.starbucks.com/article_display.cfm?article_ id=118 (accessed 5 June 2014).

Starbucks (2008). 'Starbucks refines its entertainment strategy', Press release, 24 April, available at http://news.starbucks.com/article_display.cfm?article_id=48 (accessed 5 June 2014).

Toffler, A. (1980). The Third Wave. New York: Bantam Books.

Tschmuck, P. (2012). Creativity and Innovation in the Music Industry. Berlin and Heidelberg: Springer.

Wang, X. (2012). 'Music and advertising. The influence of advertising and the media on the development of the music industry in the USA', International Journal of Music Business Research, 1(1), 21-43.

Warner Music Group (2015). Annual Report for the Fiscal Years Ended September 30, 2014. 